\title{
SEDEKAH BUMI DUSUN CISAMPIH CILACAP
}

\author{
Furqon Syarief Hidayatulloh \\ Institut Pertanian Bogor (IPB) \\ email: furqonsyarief@gmail.com
}

\begin{abstract}
This study analyzes Islamic perspective in the ritual Sedekah Bumi (earth's alms) at Dusun Cisampih, Kutabima village in Cimanggu district, at Cilacap Central Java. The method used is descriptive qualitative to describe the facts on the culture of this ritual. The finding shows that Sedekah Bumi is an ethnic ritual to show the people's high regard to the earth as a place to live in. People depend on earth as it is a place where they do farming, get food and water, and do other activities. For this reason, they feel that there should be any ceremony that shows their gratitude to the earth. Besides that, such ritual also reflects thankfulness for people's welfare and fortune and it is also believed to bring abundant crops. In Islamic perspective, this ritual accords to some Islamic principles, although some ideas are also contradicted.
\end{abstract}

Penelitian ini mengkaji perspektif Islam terhadap pelaksanaan sedekah bumi di Dusun Cisampih Desa Kutabima Kecamatan Cimanggu, Cilacap, Jawa Tengah. Metode yang digunakan yaitu deskriptif kualitatif untuk menggambarkan fakta-fakta tentang budaya perayaan sedekah bumi. Hasil temuan menunjukkan bahwa sedekah bumi menjadi perayaan adat sebagai unjud rasa syukur masyarakat Dusun Cisampih kepada Pencipta bumi karena mereka tinggal di bumi dengan anugerah-Nya. Mereka sangat bergantung kepada bumi untuk bercocok tanam, mendapatkan makanan dan minuman, serta melakukan aktifitas lainnya. Karena itu mereka merasa perlu melakukan sedekah bumi sebagai bentuk rasa terima kasih mereka kepada bumi. Selain itu, sedekah bumi juga sebagai bentuk rasa syukur atas keselamatan dan rezeki yang diterima masyarakat dan diyakini dapat mendatangkan keselamatan bagi sawah dan ladang mereka agar hasilnya melimpah. Dalam perspektif Islam, pelaksanaan upacara sedekah bumi ini ada yang bertentangan.

Keywords: sedekah bumi, Islamic perspective 


\section{Pendahuluan}

Suku Jawa mempunyai beragam kebudayaan di berbagai bagian wilayahnya, mulai dari Jawa Timur, Yogyakarta, dan sebagian wilayah Jawa Barat sebagai wilayah dominannya. Kebudayaan Jawa juga menyebar ke berbagai wilayah di luar pulau Jawa, bahkan ke luar negeri, seiring dengan migrasi penduduknya ke berbagai wilayah di luar pulau Jawa. Penyebaran itu antara lain di Indramayu, Cirebon, Banten, Lampung, Jakarta, hingga ke Suriname, Amerika Tengah.

Satu contoh dari berbagai ragam kebudayaan Jawa itu adalah sedekah bumi. Seperti ragam kebudayaan Jawa lainnya, sedekah bumi adalah kebudayaan yang sedikit banyak bermuatan nilai-nilai animisme dan dinamisme yang mendapat pengaruh Hindu-Buddha, sesuai dengan kepercayaan dan keyakinan para pendahulu masyarakat Jawa. Kepercayaan animisme dan dinamisme ini sebenarnya telah dikenal oleh bangsa Indonesia sebelum masuknya pengaruh Hindu-Budha ke Indonesia. Setelah masuk dan berkembangnya pengaruh Hindu-Budha ke Indonesia mengakibatkan akulturasi, yaitu percampuran antara kedua kepercayaan (Badrika, 2006: 121).

Nilai-nilai animisme dan dinamisme yang nampak dalam pelaksanaan sedekah bumi antara lain pemotongan hewan (seringkali kerbau) yang ditujukan sebagai persembahan kepada roh halus penguasa bumi (wilayah desa) tempat dilaksanakannya sedekah bumi. Jika rangkaian upacara sedekah bumi tidak dilaksanakan sesuai tradisi yang berlaku, seperti ritual pemotongan hewan, penduduk khawatir akan terkena murka roh halus. Murka tersebut dapat berbentuk bencana alam, menurunnya kualitas hasil bumi bahkan gagal panen, hingga terjadinya wabah penyakit pada hewan-hewan peliharaan warga. Namun belakangan terjadi perubahan paradigma pada masyarakat pelaku sedekah bumi. Pelaksanaan sedekah bumi bukan lagi sebagai ritual tolak bala atau persembahan kepada roh halus, melainkan sebagai tradisi leluhur yang harus dijalankan sebagai warisan yang menjadi kekayaan budaya masyarakat. Salah satu yang mengalami pergeseran paradigma itu adalah pelaksanaan sedekah bumi di Dusun Cisampih, sebuah dusun di tepi barat Kabupaten Cilacap, Jawa Tengah (Triyanto, 2013: 97).

Sejak jaman dahulu hingga sekarang, sedekah bumi adalah rutinitas tahunan masyarakat Dusun Cisampih. Masyarakat pada dusun yang didominasi oleh petani tersebut melakukan rangkaian upacara sedekah bumi yang pelaksanaannya sama seperti yang dijalankan oleh para leluhur, tetapi mengalami beberapa perubahan kecil. Misalnya dalam pemotongan hewan, jika dahulu kepala kerbau ikut dikuburkan ke bumi sebagai persembahan 
bersama berbagai hasil bumi lainnya, sekarang hal itu tidak lagi dilakukan kecuali hasil bumi dan sedikit makanan.

Pada generasi Dusun Cisampih kini, sedekah bumi menjadi ajang berkumpul atau silaturahim sesama masyarakat, karena di acara itu warga makan bersama. Selain itu, sebagai bentuk rasa syukur atas segala anugerah Tuhan yang mahakuasa, di dalam Islam ada perspektif tersendiri terhadap pelaksanaan ritual budaya sebagai local wisdom. Itulah yang akan dipaparkan dalam tulisan ini, yaitu perspektif Islam terhadap pelaksanaan sedekah bumi di Dusun Cisampih.

\section{Metode Penelitian}

Metode yang digunakan dalam penelitian ini adalah metode deskriptif. Metode deskriptif ini dapat digunakan untuk meneliti suatu sistem pemikiran ataupun suatu peristiwa pada masa sekarang (Nazir, 2003: 54). Pendapat lain mengungkapkan pula bahwa penelitian deskriptif adalah suatu metode penelitian yang ditujukan untuk menggambarkan fenomena-fenomena yang ada, yang langsung pada saat ini atau masa lampau (Syaodih, 2005: 54). Untuk itu, tujuan dari metode ini adalah untuk membuat deskripsi, gambaran atau lukisan yang sistematis mengenai fakta-fakta, sifat-sifat serta hubungan antar fenomena yang diselidiki (Nazir, 2003: 54). Dalam hal ini penulis menggambarkan fakta-fakta atau suatu keadaan tentang budaya perayaan sedekah bumi di Dusun Cisampih, Desa Kutabima, Kecamatan Cimanggu, Kabupaten Cilacap, Jawa Tengah.

Penelitian ini menggunakan jenis data kualitatif yang menyangkut data-data tentang masalah-masalah yang akan dibahas, yakni budaya upacara sedekah bumi. Sumber data utama dalam penelitian kualitatif adalah kata-kata dan tindakan, selebihnya adalah tambahan seperti dokumen (Moleong, 2006: 157). Adapun jenis datanya di bagi kedalam kata-kata dan tindakan, sumber data tertulis, foto, dan statistik (Moleong, 2006: 157). Dari keempat jenis data tersebut, jenis data yang dijadikan kajian dalam penelitian ini adalah jenis data kata-kata dan tindakan serta sumber data tertulis sebagai pendukung.

Sumber data tertulis dapat dibagi atas sumber buku dan majalah ilmiah, sumber dari arsip, dokumen pribadi, dan dokumen resmi (Moleong, 2006: 159). Secara dominan, tulisan ini menggunakan data tertulis berupa buku dan jurnal ilmiah. Adapun teknik pengumpulan bahan dalam penelitian ini sesuai dengan teknik pengumpulan data yang berlaku dalam penelitian kualitatif, yaitu dengan cara observasi, wawancara, studi dokumentasi dan triangulasi (Sugiono, 2005: 63). 


\section{Pembahasan}

\section{Pengertian Sedekah Bumi}

Istilah sedekah bumi berasal dari bahasa Jawa sedekah desa. Dalam kamus Besar Bahasa Indonesia, sedekah mengandung beberapa arti, antara lain: pertama, pemberian sesuatu kepada fakir miskin atau yang berhak menerimanya, di luar kewajiban zakat dan zakat fitrah sesuai dengan kemampuan yang memberi. Kedua, selamatan. Ketiga, makanan (bunga-bunga dsb) yang disajikan kepada orang halus (roh penunggu dsb); - arwah-- sedekah yang diadakan untuk menghormati dan mendoakan orang yang meninggal.; - bumi-selamatan yang diadakan sesudah panen (memotong padi) sebagai tanda bersyukur (KKBI, 2008). Sedekah bumi adalah pemberian kepada bumi. Makna kata sedekah berarti pemberian sukarela yang tidak ditentukan peraturan-peraturan tertentu, baik berkaitan dengan jumlah maupun jenis yang disedekahkan (Bara Wati, 2013: 16).

Dari beberapa pengertian yang diungkapkan di atas dapat dipahami bahwa secara umum sedekah bumi adalah kegiatan berupa selamatan atau pemberian kepada bumi sebagai wujud rasa syukur yang dilaksanakan sesudah panen. Dalam tradisi budaya Jawa khususnya masyarakat Dusun Cisampih Jawa Tengah, sedekah bumi ini diartikan dengan sebuah perayaan adat sebagai bentuk rasa syukur masyarakat. Masyarakat tinggal di muka bumi. Mereka bercocok tanam juga menggunakan bumi (tanah) sebagai medianya, sehingga bisa memanen hasil bumi yang melimpah. Karena itu mereka merasa perlu melakukan sedekah bumi sebagai bentuk rasa terima kasih mereka kepada bumi. Selain itu, sedekah bumi juga sebagai bentuk rasa syukur atas keselamatan dan segala rezeki yang diterima masyarakat selama tinggal di bumi (Triyanto, 2013: 57).

\section{Tujuan Upacara Sedekah Bumi}

Dalam sejarah budaya Jawa, pelaksanaan upacara sedekah bumi berawal dari tradisi pemujaan terhadap roh halus atau penghormatan kepada leluhur. Sedekah bumi dilaksanakan oleh masyarakat dalam kaitannya untuk memberi persembahan kepada arwah leluhur atau penguasa jagat. Dalam pandangan orang Jawa-Hindu sedekah bumi merupakan persembahan terhadap Dewi Sri atau dewa kesuburan (Ashari, 2001: 62).

Sedekah bumi menunjukan adanya kepercayaan terhadap animisme dan dinamisme, yakni keyakinan terhadap adanya kekuatan lain di luar diri manusia berupa roh atau dewa yang mampu mempengaruhi dalam kehidupannya (Ashari, 
2001: 62). Maksud dan tujuan pelaksanaan sedekah bumi ini adalah untuk mencari keselamatan hidup, dengan cara melaksanakan selametan bersamasama pada setiap bulan Sura (Jawa) atau Muharram dalam sistem kalender Hijriyah. Dalam perkembangan selanjutnya, seiring dengan perkembangan pola pemikiran dan budaya masyarakat, tujuan pelaksanaan sedekah bumi ini, di kebanyakan lokasi yang penduduknya muslim, mengalami pergeseran dari waktu ke waktu. Bagi masyarakat Dusun Cisampih Jawa Tengah, pelaksaaan sedekah bumi juga merupakan perwujudan rasa syukur kepada Tuhan yang Maha Kuasa, walaupun praktik pelaksanaannya tidak jauh berbeda dengan tradisi awal (Triyanto, 2013: 51).

Sepadan dengan ungkapan di atas, hal yang paling mendasar dalam pelaksanaan sedekah bumi adalah adanya motivasi untuk mencari ketenangan batin dan keyakinan adanya kekuatan lain di luar manusia, baik roh halus atau arwah leluhur maupun sesuatu yang ghaib lainnya. Oleh karenanya, diperlukan penghormatan dengan cara melaksanakan sedekah bumi. Dalam hal ini sedekah bumi dipandang sebagai bentuk rasa syukur masyarakat. Dalam pandangan masyarakat, mereka tinggal di bumi, mendapatkan makan dan minum dari bumi, bercocok tanam juga menggunakan bumi (tanah) sebagai medianya, sehingga bisa memanen hasil bumi yang melimpah, dan mereka melakukan semua aktivitas juga di bumi. Karena itu, mereka merasa perlu melakukan sedekah sebagai bentuk rasa terima kasih kepada bumi. Selain itu, sedekah bumi juga sebagai bentuk rasa syukur atas keselamatan dan segala rezeki yang diterima masyarakat selama tinggal di bumi.

Dengan demikian, maksud dan tujuan pelaksanaan upacara sedekah bumi ini dapat dikatakan, satu sisi sebagai wujud ekspresi masyarakat untuk mendapatkan ketenangan batin dan keselamatan hidup dari berbagai gangguan pengaruh roh halus atau leluhur maupun makhluk ghaib lainnya, di sisi lain sebagai wujud ekspresi kegembiraan (syukur) atas keberhasilan atau keselamatan serta segala rezeki yang diterimanya selama tinggal di bumi.

Keyakinan masyarakat untuk mencari ketenangan dan keselamatan melalui upacara sedekah bumi ini dapat dikatakan keyakinan yang berbau pemahaman animisme dan dinamisme. Pemahaman ini dalam perspektif Islam sangat jauh atau dengan bahasa lain bertentangan dengan nilai-nilai tauhid. Dalam keyakinan masyarakat yang melakukan sedekah bumi, seakanakan yang meberikan ketenangan, kemakmuran dan keselamatan itu adalah roh halus, leluhur atau kekuatan ghaib lainnya, padahal dalam ajaran Islam, semua itu tidak memiliki kemampuan untuk memberikan manfaat atau 
madharat apa pun kepada manusia, bahkan mereka itu tidak mengetahui apa-apa sebagaimana firman Allah SWT:

"Dan pada sisi Allah-lah kunci-kunci semua yang ghaib; tak ada yang mengetahuinya kecuali Dia sendiri..."(QS al An'aam 6:59).

Kemudian dalam ayat lain disebutkan,

"Katakanlah: "Tidak ada seorangpun di langit dan di bumi yang mengetahui perkara yang ghaib, kecuali Allah",(QS an Naml 27:65).

Kaitannya dengan penciptaan, pemeliharaan dan pemberian rezeki, Allah SWT berfirman:

"Allah menciptakan segala sesuatu dan Dia memelihara segala sesuatu. (QS. az Zumar 39: 62),

Dalam ayat lainnya:

"Dan tidak ada suatu binatang melatapun di bumi melainkan Allah-lah yang memberi rezkinya, dan Dia mengetahui tempat berdiam binatang itu dan tempat penyimpanannya. Semuanya tertulis dalam kitab yang nyata (Lauh Mahfuzh) (QS Hud 11: 6).

Kemudian firman-Nya,

"Sesungguhnya Allah menumbuhkan butir tumbuh-tumbuhan dan biji buah-buahan. Dia mengeluarkan yang hidup dari yang mati dan mengeluarkan yang mati dari yang hidup. (yang memiliki sifat-sifat) yang demikian ialah Allah, maka mengapa kamu masih berpaling?"(QS al An'aam 6:95-96).

Dalam keyakinan Islam, Dzat Yang Maha mampu untuk memberikan ketenangan, keselamatan, kemakmuran hanyalah Allah SWT. Untuk itu, ketika manusia ingin mendapatkan ketenangan, keselamatan, kemakmuran hendaknya beriman dan merapat kepada-Nya dengan melakukan segala aktivitas sesuai dengan aturanNya. Dalam kaitannya dengan hal ini, Allah SWT menegaskan dalam al Qur'an:

"(yaitu) orang-orang yang beriman dan hati mereka manjadi tenteram dengan mengingat Allah. Ingatlah, hanya dengan mengingati Allah-lah hati menjadi tenteram.(QS ar Ra'du 13:28)."

Kemudian dalam ayat lain:

" Barangsiapa yang mengerjakan amal saleh, baik laki-laki maupun perempuan dalam Keadaan beriman, maka sesungguhnya akan Kami berikan kepadanya kehidupan yang 
baik dan sesungguhnya akan Kami beri Balasan kepada mereka dengan pahala yang lebih baik dari apa yang telah mereka kerjakan. (QS an Nahl 16:97)”.

Begitu pula yang mampu memberikan madharat dan kebaikan bukan roh halus dan leluhur melainkan Allah SWT, sebagaimana ditegaskan dalam firman-Nya,

"Jika Allah menimpakan sesuatu kemudharatan kepadamu, maka tidak ada yang dapat menghilangkannya kecuali Dia. Dan jika Allah menghendaki kebaikan bagi kamu, maka tak ada yang dapat menolak kurnia-Nya. Dia memberikan kebaikan itu kepada siapa yang dikehendaki-Nya di antara hamba-hamba-Nya dan Dia-lah Yang Maha Pengampun lagi Maha Penyayang (QS Yunus 10:107)

Dalam ayat lain dikatakan,

"Katakanlah: "Sesungguhnya karunia itu di tangan Allah, Allah memberikan karuniaNya kepada siapa yang dikehendaki-Nya; dan Allah Maha Luas (karunia-Nya) lagi Maha Mengetahui"; (QS Ali Imran 3:73)

Selanjutnya, keyakinan masyarakat yang menjadikan ritual sedekah bumi sebagai wujud syukur kepada bumi karena bumi dianggap telah memberikan bermacam sumber kehidupan seperti makanan, telah sesuai dengan ajaran Islam, namun ketika syukurnya itu ditujukan ke bumi, bukan kepada pemilik bumi yakni Allah SWT, hal ini bertentangan dengan ajaran Islam, karena dalam ajaran Islam syukur itu harus ditujukan kepada Allah SWT, bukan kepada bumi. Bumi diciptakan oleh Allah SWT, tanaman diciptakan, ditumbuhkan sekaligus dipelihara oleh Allah SWT (QS az Zumar 39:62). Jadi bersyukurnya pun harus kepada Allah Swt, sebagaimana tercermin dalam firman-Nya:

"Karena itu, ingatlah kamu kepada-Ku niscaya Aku ingat (pula) kepadamu, dan bersyukurlah kepada-Ku, dan janganlah kamu mengingkari (ni mat) -Ku (QS al Baqarah 2:152).

Kemudian ditegaskan pula dalam ayat lain:

"Dan (ingatlah juga), tatkala Tuhanmu mema lumkan: "Sesungguhnya jika kamu bersyukur, pasti Kami akan menambah (ni' mat) kepadamu, dan jika kamu mengingkari (ni`mat-Ku), maka sesungguhnya azab-Ku sangat pedih." (QS Ibrahim 14:7)

\section{Pelaksanaan Upacara}

Upacara sedekah bumi oleh masyarakat Dusun Cisampih Desa Kutabima Kabupaten Cilacap ini dilaksanakan pada bulan Sura setiap tahunnya. Adapun yang menjadi alasan terpilihnya bulan Sura, karena pada jaman Nabi Nuh, 
bumi tertutup air oleh banjir bandang. Kemudian air surut dan kehidupan di bumi dimulai lagi. Menurut cerita turun-temurun dari tradisi lisan masyarakat Cisampih, Sura adalah bulan surutnya air banjir itu dan sekaligus dimulainya kehidupan lagi di muka bumi (Rastono, 2013: 42).

Di samping bulannya yang harus tepat, hari pelaksanaannya pun tidak boleh sembarangan. Jika tidak hari Selasa Kliwon, perayaan sedekah bumi dilakukan pada hari Jumat Kliwon. Tidak boleh di luar dua hari itu. Pada bulan Sura tersebut hanya akan ditemui satu Selasa Kliwon atau satu Jumat Kliwon saja. Untuk menentukan harinya, dilakukan musyawarah adat oleh para petinggi adat sehingga akan disepakati hari jatuhnya pelaksanaan sedekah bumi (Sunarmo, 2013: 76). Hari Selasa Kliwon itu hanya merupakan alternatif jika pelaksanaan pada hari Jumat Kliwon tidak bisa. Namun pada kenyataannya, upacara sedekah bumi sering diselenggarakan pada hari Jumat Kliwon. Dalam tradisi wetonan masyarakat Jawa, Jumat adalah rajanya hari, sedangkan kliwon merupakan rajanya pasaran (hitungan wetonan menurut kalender Jawa, yaitu legi, pahing, pon, wage, dan kliwon).

Jika jatuhnya hari sedekah bumi sudah ditentukan, malamnya akan diadakan hiburan. Biasanya hiburan yang diselenggarakan berupa musik ronggeng. Hiburan tersebut akan terselenggara jika kondisi keuangan masyarakat bagus. Jika kondisi keuangan sebaliknya, acara tersebut tidak bisa terselenggara. Hal ini disebabkan pelaksanaan hiburan ini sumber dananya berasal dari iuran masyarakat. Ketika keuangan masyarakat tidak bagus, pada malam menjelang acara sedekah bumi akan dilaksanakan selawatan sepanjang malam di pusat dusun. Kisaran biaya untuk pelaksanaan rangkaian kegiatan sedekah bumi ini sekitar enam belas juta rupiah.

Jika hiburan ronggeng dilaksanakan, anggota masyarakat yang memiliki hewan besar seperti sapi dan kerbau akan ngibing (berjoget) di panggung. Saat ngibing tersebut, akan ada tokoh adat yang melakukan ombyok sapi. Ombyok sapi adalah kegiatan menebar dadung (dadung adalah tali pengikat leher sapi) yang caranya dilakukan seperti menjala ikan. Tokoh adat tersebut 'menjala' pemilik hewan yang sedang ngibing bersama penari ronggeng (penari yang sekaligus merangkap penyanyi). Penari ronggeng dan pemilik hewan tersebut disatukan dalam ikatan dadung. Tidak harus sampai bersentuhan, hanya sebagai 'simbol'.

Setelah selesai ngibing dan 'dijala', pemilik hewan turun dari panggung sambil mengambil padi di pinggir panggung, di mana telah disediakan satu tumpukan padi yang masih bertangkai. Pemilik hewan yang selesai ngibing itu 
kemudian mengambil satu tangkai padi yang akan dicampurkan dengan benih yang akan ditanam pada masa tanam yang akan datang. Setangkai padi yang diambil dari acara ombyok sapi ini dipercaya akan membawa berkah kesuburan pada padi-padi yang ditanam. Semua pemilik hewan besar seperti kerbau dan sapi harus mau melakukan ombyok sapi dan ngibing dengan ronggeng (Sunarmo, 2013: 78).

Ombyok sapi dilakukan juga untuk keselamatan hewan ternak. Jika pemilik hewan tidak melakukan ombyok sapi, dikhawatirkan akan ada penyakit yang menyerang hewannya. Dahulu pernah terjadi peristiwa besar, hewan-hewan tidak bisa berjalan (kakinya seperti lumpuh mendadak). Itu terjadi secara massal. Sejak itulah dilaksanakan ombyok sapi. Menurut kepercayaan masyarakat Cisampih pada zaman dahulu, setiap ada suatu kejadian berarti bumi sedang 'meminta' sesuatu, semacam persembahan. Persembahan pada sedekah bumi pun merupakan 'permintaan' dari dangiang, istilah untuk lelembut penguasa dusun. Misalnya jenis hewan yang disembelih harus kerbau bule. Kemudian hiburan yang diselenggarakan harus ronggeng. Hiburan yang diadakan pun berbeda-beda antarwilayah. Misalnya di daerah yang berbatasan dengan Cisampih, hiburan yang diminta dangiang adalah wayang golek (Triyanto, 2013: 66).

Jika tidak diadakan hiburan ronggeng, maka diadakan selawatan. Tempat dilaksanakannya selawatan tidak selalu tetap pada setiap tahunnya. Dusun Cisampih sendiri dibagi beberapa kampung yaitu Pentas, Bantarsari, Bisole, Dukuh Kadu, Ciwulung, Cicadas, Cisereh, dan Cibiru. Pada kampungkampung itulah setiap tahunnya bergiliran dilaksanakan selawatan di malam menjelang pelaksanaan acara sedekah bumi.

Pelaksanaan hiburan ronggeng tersebut pada dasarnya dilakukan dengan rutin, yaitu tiga tahun sekali. Karena rutinitasnya itulah masyarakat memang sudah menyisihkan uangnya untuk kegiatan hiburan ronggeng. Seiring dengan itu, kegiatan sedekah bumi pun dilaksanakan terpusat di dusun dan terkadang di masing-masing kampung. Terpusat di dusun tiga tahun sekali sesuai dengan pelaksanaan hiburan ronggeng. Untuk sedekah bumi pada masing-masing kampung dilaksanakan pada dua tahun lainnya.

Jika sedekah bumi dilaksanakan secara terpusat, hewan yang dipotong pada acara tersebut harus seekor kerbau bule, yaitu kerbau yang bulunya berwarna pirang. Sementara jika pelaksanaan sedekah bumi pada masing-masing kampung, hewan yang dipotong adalah kambing dengan tidak ada ketentuan warna bulu ataupun jenisnya. Hewan yang dipotong tersebut diperoleh dari 
dana iuran masyarakat. Namun di luar kedua jenis hewan tersebut, biasanya masing-masing keluarga juga memotong seekor ayam. Namun itu tidak mutlak, keluarga yang berkehendak saja, sebagai tambahan lauk (Sunarmo, 2013).

Puncak pelaksanaan sedekah bumi adalah pada keesokan harinya, yaitu pada hari $\mathrm{H}$, dimulai pada pagi hari. Pada pusat dusun atau pusat kampung (tergantung tahun pelaksanaan), dibuat sebuah lubang besar. Biasanya lubang tersebut dibuat atau berada di perempatan jalan, karena jalanan memang tidak diaspal. Tempat pembuatan lubang di pusat dan perempatan jalan dimaksudkan sebagai keselamatan. Sedekah bumi sendiri merupakan prosesi yang di dalamnya termuat unsur pencarian selamat. Oleh karena itu, jika lubangnya berada di pusat, diharapkan semua orang bisa melewatinya dan semuanya selamat dalam kehidupan. Kembali kepada masalah pembuatan lubang, penggaliannya dilakukan pagi-pagi sekali. Setelah lubang selesai digali, dilakukanlah penyembelihan kerbau atau kambing. Darahnya dialirkan ke lubang yang sudah digali tersebut. Setelah menyembelih kerbau atau kambing, berdatangan juga orang-orang yang hendak menyembelihkan ayam, darahnya juga dialirkan ke lubang tersebut. Orang yang menyembelih kerbau atau kambing, termasuk menyembelih ayam, tidak boleh orang sembarangan. Orang yang berhak menyembelih adalah tetua adat atau orang yang dituakan di kampung. Setelah penyembelihan selesai, lubang akan ditinggalkan. Masyarakat pulang ke rumah masing-masing dan disibukkan dengan acara masak. Kerbau atau kambing yang telah disembelih dibawa dan dimasak oleh orang-orang yang ditunjuk (petugas adat). Setelah matang akan dibagi-bagikan kepada masingmasing keluarga. Sementara itu pada masing-masing keluarga juga masak nasi tumpeng, berbagai jenis olahan sayur, goreng-gorengan, dan berbagai jenis makanan lainnya (Triyanto, 2013: 101).

Setelah agak siang, tetua adat akan memukul kentongan dari dekat lubang penyembelihan. Itu adalah tanda bahwa masyarakat diminta berkumpul. Pada saat itulah masing-masing keluarga membawa nasi tumpeng lengkap dengan berbagai sayur dan lauknya. Mereka membentuk lingkaran mengitari lubang. Setelah semua berkumpul, tetua adat akan menghampiri setiap keluarga, mengambil sebagian nasi tumpeng dan berbagai lauk pelengkapnya. Sang tetua mengambilnya masing-masing sedikit. Makanan serba sedikit yang diambil tetua adat dari masing-masing keluarga tersebut kemudian dimasukkan ke dalam lubang. Bersama itu pula dimasukkan padi, singkong, dan berbagai hasil bumi lainnya. Semua benda yang diambil tersebut serba sedikit.

Setelah masyarakat melakukan tahlilan bersama-sama. Kemudian 
dilanjutkan dengan doa oleh tetua adat. Semua itu dijalankan di dekat lubang. Kadang mengitari lubang. Jika tidak memungkinkan, tidak mengitari lubang tetapi tetap dilaksanakan tidak jauh dari lubang. Lalu acara sedekah bumi akan ditutup dengan makan bersama. Sisa makan bersama seperti bungkus ketupat dan berbagai sisa lainnya yang tidak layak makan, dimasukkan ke dalam lubang. Kemudian lubang itu ditutup dengan tanah. Masyarakat pun pulang ke rumah masing-masing dengan perasaan suka cita.

Kegiatan sedekah bumi masih terus berjalan setiap tahunnya sampai saat ini. Namun dalam perkembangannya, ada pergeseran paradigma pada masyarakat. Dahulu rangkaian upacara sedekah bumi ini merupakan sebuah upacara yang berdasarkan keyakinan. Masyarakat percaya bahwa jika sedekah bumi tidak dilaksanakan, ada kekhawatiran tentang keselamatan hidup serta keberhasilan panen, karena dengan tidak melakukan sedekah bumi berarti mereka tidak bersyukur dan tidak melakukan 'balas budi' kepada bumi. Namun kepercayaan itu perlahan bergeser. Pada masa kini, masyarakat melakukan rangkaian upacara sedekah bumi semata-mata menjalankan tradisi. Pada kesempatan tersebut masyarakat berkumpul, makan bersama, dan bergembira bersama, sebagai ajang silaturahim (Triyanto, 2013: 107), walaupun paradigmanya sudah berbeda, praktik pelaksanaannya masih tetap sama.

Dari berbagai informasi yang dikemukakan di atas, baik yang berkaitan dengan penentuan waktu, aktivitas pada malam hari menjelang pelaksanaan, maupun hari puncak pelaksanaan, di dalamnya terkandung beberapa nilai positif, antara lain:

Pertama, musyawarah. Hal ini terjadi ketika petinggi adat akan memutuskan hari pelaksanaan sedekah bumi. Dalam Islam, pada dasarnya musyawarah dalam menentukan suatu urusan merupakan sesuatu yang disyariatkan sebagaimana tercermin dalam firman Allah SWT:

Maka disebabkan rahmat dari Allah-lah kamu berlaku lemah-lembut terhadap mereka. Sekiranya kamu bersikap keras lagi berhati kasar, tentulah mereka menjauhkan diri dari sekelilingmu. Karena itu ma afkanlah mereka, mohonkanlah ampun bagi mereka, dan bermusyawaratlah dengan mereka dalam urusan itu. Kemudian apabila kamu telah membulatkan tekad, maka bertawakkallah kepada Allah. Sesungguhnya Allah menyukai orang-orang yang bertawakkal kepada-Nya. (QS Ali Imran 3:159).

Kedua, gotong royong. Dari iuran yang dilakukan masyarakat menunjukan adanya kerjasama dan kekompakkan yang dilakukan warga masyarakat dalam mempersiapkan kebutuhan-kebutuhan untuk merayakan sedekah bumi. Nilainilai ini pada dasarnya termasuk hal yang baik. Namun demikian, ketika hasil 
iuran itu digunakan untuk sesuatu yang bertentangan dengan nilai Islam akan menjadi hal yang sebaliknya, bahkan dilarang, "wala ta'aawanu 'alal ismi wal 'udwaan".

Ketiga spiritual-cinta Rasul. Membaca shalawat kepada Nabi SAW. termasuk perbuatan yang diperintahkan oleh Allah Swt. sebagaimana dinyatakan dalam firman-Nya:

"Sesungguhnya Allah dan malaikat-malaikat-Nya bershalawat untuk Nabi. Hai orang-orang yang beriman, bershalawatlah kamu untuk Nabi dan ucapkanlah salam penghormatan kepadanya. (QS. al Ahzab 33:56).

Dalam hadits juga dinyatakan, "dari Abdullah bin Amr al-Ash r.a bahwa ia mendengar Rasulullah Saw. bersabda,

"Barangsiapa yang bershalawat kepadaku satu kali shalawat, Allah pasti memberi shalawat (mencurahkan rahmat) kepadanya karena shalawat tersebut sebanyak sepuluh kali lipat." (HR Muslim).

Kemudian dari Ibnu Mas'ud r.a bahwa Rasulullah SAW bersabda,

"Manusia yang paling utama denganku pada hari kiamat adalah yang paling banyak bershalawat kepadaku." (HR at Tirmidzi).

Dalam hadits lain, dari Abu Hurairah r.a Bahwa Rasulullah SAW bersabda,

"Setiap kali seorang muslim mengucapkan salam kepadaku, pasti Allah mengembalikan ruhku sampai aku dapat menjawab salam kepadanya." (HR Abu Daud)

Berdasarkan beberapa hadits di atas, menunjukkan bahwa orang yang senantiasa membaca shalawat kepada Rasul akan mendapatkan kebaikan. Untuk itu, membaca shalawat termasuk perbuatan yang mulia. Keempat, silaturrahim-kasih sayang. Pertemuan warga masyarakat dalam rangka berbagi makanan sekaligus makan bersama merupakan hal yang baik yang dianjurkan dalam Islam. Kondisi seperti ini akan menumbuhkan kebersamaan, kasih sayang, saling memaafkan dan pada akhirnya akan menghilangkan unek-unek di antara mereka. Hal ini tercermin dalam sebuah Hadits,

"Saling memberi hadiah kalian, niscaya kalian akan saling kasih mengasihi, dan saling maaf memaafkan, niscaya rasa unek-unek akan lenyap dari diri kalian." (HR. Ibn Asakir) (Ahmad, tt: 62). 
Silaturahim ini merupakan hal yang diperintahkan dalam Islam karena silaturahim mempunyai beberapa keutamaan, diantaranya adalah (al Samarqondi, tt: 49): (1) Mengundang keridhaan Allah SWT karena silaturahim merupakan perintah-Nya; (2) Mendatangkan kesenangan dan kebahagiaan; (3) Disenangi Malaikat; (4) Menambah (keberkahan) umur dan rezeki; (5) dapat menumbuhkan kecintaan; (6) Menambah kebahagiaan dan kesenangan bagi orang-orang yang telah meninggal dunia (orang yang telah meninggal merasa senang terhadap keluarganya yang masih hidup yang senantiasa memelihara silaturahmi

Disamping mengandung unsur-unsur positif, upacara sedekah bumi ini juga mengandung unsur-unsur yang bertentangan dengan ajaran Islam. Nilai-nilai itu antara lain:

Pertama, sedekah bumi dilaksanakan pada waktu tertentu yaitu bulan Sura dengan alasan sebagaimana diungkapkan di atas. Pada jaman Nabi Nuh bumi tertutup oleh air. Kemudian air surut dan kehidupan di bumi dimulai lagi. Menurut cerita turun-temurun di Cisampih, Sura adalah bulan surutnya air laut sekaligus dimulainya kehidupan di bumi. Penentuan waktu sedekah bumi ini jika disakralkan sebagai waktu khusus karena dipandang suatu kebenaran untuk melaksanakan ibadah ritual tertentu seperti syukuran atas anugerah yang didapatkannya atau memohon keselamatan dari berbagai gangguan, termasuk sesuatu yang mengada-ada. Hal ini jelas bertentangan dengan ajaran Islam. Dalam Islam, pada dasarnya bersyukur dan bermunajat kepada Allah SWT senantiasa dapat dilakukan kapan dan di mana saja, tidak ada batasan dan waktu tertentu.

Kedua, menjelang pelaksanaan sedekah bumi, malamnya diadakan hiburan berupa musik ronggeng. Ketika acara hiburan dimulai, anggota masyarakat yang memiliki hewan besar seperti sapi atau kerbau akan ngibing (berjoget) di panggung. Saat ngibing tersebut, akan ada tokoh adat yang melakukan ombyok sapi (menebar dadung) yang caranya dilakukan seperti menjala ikan. Tokoh adat tersebut 'menjala' pemilik hewan yang sedang ngibing bersama penari ronggeng (sekaligus penyanyi). Penari ronggeng dan pemilik hewan tersebut disatukan dalam ikatan dadung. Setelah selesai ngibing pemilik hewan langsung turun untuk mengambil satu tangkai padi yang akan dicampurkan dengan benih yang akan ditanam pada masa tanam yang akan datang. Setangkai padi yang diambil dari acara ombyok sapi ini dipercaya akan membawa berkah kesuburan pada padi-padi yang ditanam sekaligus untuk keselamatan hewan ternak. Jika pemilik hewan tidak melakukan ombyok sapi, dikhawatirkan akan ada 
penyakit yang menyerang hewannya. Dalam perspektif Islam, aktivitas tersebut yang sangat kritis adalah adanya keyakinan bahwa dengan ombyok sapi akan mendatangkan keberkahan dan kesuburan bagi tanaman serta mendatangkan keselamatan bagi hewan. Hal ini jelas bertentangan dengan ajaran tauhid. Sebab, dalam keyakinan ajaran Islam hanya Allah-lah yang Maha Mengatur (al Mudabbir), yang mampu mendatangkan keselamatan dan kemadaratan (QS Yunus 10: 107). Hanya Allah SWT yang mampu menumbuhkan biji-bijian. (QS al An'aam 6:95-96).

Ketiga, pada waktu puncak pelaksanaan sedekah bumi, di pusat dusun atau pusat kampung, dibuat sebuah lubang besar yang dimaksudkan sebagai keselamatan dan diharapkan semua orang bisa melewatinya dan semuanya selamat dalam kehidupan. Sebelumnya, dilakukan penyembelihan kerbau atau kambing yang darahnya dialirkan ke lubang tersebut. Setelah agak siang, masing-masing keluarga membawa nasi tumpeng lengkap dengan berbagai sayur dan lauknya. Mereka membentuk lingkaran mengitari lubang. Setelah semua berkumpul, tetua adat akan menghampiri setiap keluarga, mengambil sebagian nasi tumpeng dan berbagai perlengkapannya. Makanan yang diambil oleh tetua adat dari masing-masing keluarga tersebut kemudian dimasukkan ke dalam lubang. Bersama itu pula dimasukkan padi, singkong, dan berbagai hasil bumi lainnya. Dalam perspektif Islam, hal demikian termasuk bertentangan dengan ajaran Islam, bertentangan dengan tauhid, karena mengandung syirik, keyakinan animisme-dinamisme. Dalam hal ini Rasulullah SAW tidak pernah mencontohkannya, Rasulullah tidak pernah membuat lubang kemudian dimasukan bermacam makanan sebagai bentuk syukur dan mencari keselamatan dan keberkahan, sesuai dengan hadits:

"Barangsiapa yang melakukan amalan bukan menurut ajaran kami, maka amalan itu tertolak." (HR Muslim) (Qardhawi, 1996: 94).

Disamping itu, dengan adanya upacara memasukan makanan; padi, singkong dan hasil bumi lainnya termasuk kategori mubadzir (boros) yang dilarang. Dalam hal ini Allah SWT berfirman:

"Sesungguhnya pemboros-pemboros itu adalah saudara-saudara syaitan dan syaitan itu adalah sangat ingkar kepada Tuhannya.(QS al Isra:27).

Dalam hadits dikatakan, Abu Hurairah r.a berkata, Rasulullah SAW bersabda:

"Sesungguhnya Allah meridhai tiga hal dan membenci tiga hal bagi kalian. Dia meridhai kalian untuk menyembah-Nya, dan tidak menyekutukan sesuatu pun dengan-Nya, serta berpegang teguh kalian seluruhnya pada tali Allah dan tidak terpecah belah. Dia pun 
membenci tiga hal bagi kalian, menceritakan sesuatu yang tidak jelas sumbernya, banyak bertanya, dan membuang-buang harta." (HR Muslim) (Zakaria, 1994: 640).

Kaitannya dengan masalah makanan ini, jangankan dibuang begitu saja, apabila ada sedikit dari makanan yang jatuhpun, hendaklah diambil dan dibersihkan kotorannya lalu dimakan, karena Rasulullah SAW bersabda:

"Apabila suapan makanan salah seorang di antara kamu itu jatuh maka hendaklah ia mengambilnya, menghilangkan kotorannya, lalu memakannya, dan janganlah ia membiarkannya untuk syetan." (HR Muslim) (al Jazairi, 1995: 109).

Kemudian hal lain yang bertentangan dengan ajaran Islam pada puncak sedekah bumi adalah menyembelih hewan yang bukan karena Allah, tapi dipersembahkan untuk roh halus, leluhur atau yang ghaib lainnya, dalam Islam perbuatan ini termasuk syirik yang harus dijauhi (QS al Maidah 5: 3). Namun jika penyembelihan hewan ini dilakukan karena Allah, maka dibolehkan seperti yang terjadi pada sebagian masyarakat Dusun Cisampih belakangan ini.

Dengan demikian, secara umum upacara sedekah bumi yang dilakukan oleh masyarakat Dusun Cisampih ini masih banyak mengandung unsur-unsur yang bertentangan dengan nilai-nilai ajaran Islam. Tujuan pelaksanaan kegiatan ini adalah untuk mengekspresikan rasa syukur yang merupakan ajaran Islam, namun ketika praktiknya tidak sesuai dengan tuntunan Islam, tetap menjadi hal yang tidak diperbolehkan .

Jika sedekah bumi ini dimaksudkan sebagai wujud syukur atas nikmat dan karunia Allah, hendaknya bersyukur mengikuti ajaran Islam. Padahal, syukur yang sebenarnya adalah ketika seseorang mendapatkan kenikmatan yang telah dianugrahkan Allah SWT kepadanya, seperti nikmat kesehatan, nikmat harta benda dan kehormatan, dia memanfaatkan kenikmatan tersebut sebaik-baiknya, sehingga dapat memberi manfaat baik bagi dirinya sendiri dan orang lain (Sabiq, 1992: 73-74). Syukur tersebut tersusun dari tiga perkara, yaitu: al'ilmu, al hal dan al'amal. Al'ilmu maksudnya mengetahui bahwa kenikmatan itu (datang) dari Dzat yang memberi nikmat (Allah SWT). Al hal maksudnya suatu kondisi (hati) merasa senang dengan adanya nikmat itu. Al 'amal maksudnya memanfaatkan kenikmatan tersebut (sesuai) dengan tujuan pemberi nikmat (Allah SWT). Kaitannya dengan amal ini meliputi beberapa hal, yaitu; (1) al 'amal bil qalbi (amal dengan hati), yaitu dengan bermaksud berbuat kebaikan serta menyembunyikannya (dari pandangan orang lain); (2) al'amalu bil lisan (amal dengan lisan) yaitu menampakkan syukur kepada Allah 
SWT dengan pujian seperti membaca tahmid (alhamdulillah); dan (3) al'amal bil jawarih (amal dengan anggota badan) yaitu memanfaatkan dan mengoptimalkan nikmat Allah dalam rangka ketaatan kepada-Nya (al Qasimi, tt: 349).

Bersyukur dengan cara yang benar atas segala kenikmatan yang telah dianugrahkan Allah Swt merupakan kewajiban setiap muslim. Sebagaimana dinyatakan dalam firman-Nya,

"Dan (ingatlah juga), tatkala Tuhanmu mema" lumkan: "Sesungguhnya jika kamu bersyukur, pasti Kami akan menambah (ni' mat) kepadamu, dan jika kamu mengingkari (ni`mat-Ku), maka sesungguhnya azab-Ku sangat pedih” (QS Ibrahim:7).

Dalam kaitannya dengan ayat ini, diungkapkan dalam tafsir Jalalain, jika kalian bersyukur atas nikmatku dengan tauhid dan thaat, niscaya aku akan tambahkan (nikmat) kalian. Dan jika kalian mengkufurinya dengan melakukan kekufuran dan kemaksiatan, niscaya aku akan mengazab kalian (al Muhilli, tt: 207). Dalam tafsir al Futuhat diungkapkan juga bahwa jika kalian bersyukur dengan taat niscaya aku tambahkan pahala kalian (al 'Ajili al Syafii, tt: 515). Syukur sebenarnya akan menjadi penolak dan pencegah terhadap datangnya azab (Sabiq, 1992: 75). Hal ini menggambarkan betapa besar manfaat bersyukur bagi yang mengamalkannya.

\section{Simpulan}

Dari uraian di atas dapat ditarik simpulan bahwa sedekah bumi merupakan tradisi yang dilakukan sejak dulu. Upacara ini dilaksanakan sebagai bentuk persembahan kepada leluhur dan wujud rasa syukur masyarakat kepada (Pencipta) bumi. Selain itu, sedekah bumi diyakini dapat mendatangkan ketenangan batin warga dan keselamatan bagi sawah dan ladang mereka, karena dengan sedekah bumi tersebut hasilnya akan melimpah. Apabila proses upacara sedekah bumi ini tidak dilaksanakan, timbul kekhawatiran terhadap keselamatan hidup serta keberhasilan panen. Dengan tidak melakukan sedekah bumi berarti dianggap tidak bersyukur dan tidak melakukan 'balas budi' kepada bumi.

Pelaksanaan sedekah bumi ini mengandung beberapa unsur yang dapat dipandang sebagai kebaikan, antara lain: terciptanya suasana kebersamaan dan persaudaraan, terciptanya suasana gotong royong dan kerjasama, serta membangun jiwa pengorbanan. Nilai-nilai ini pada prinsipnya tidak bertentangan dengan nilai Islam. Namun di sisi lain, upacara sedekah bumi mengandung juga unsurunsur yang bertentangan dengan ajaran Islam, bahkan termasuk perbuatan syirik. Adanya keyakinan masyarakat bahwa sedekah bumi dengan bermacam 
perayaanya seperti ombyok sapi akan mendatangkan keselamatan, kesuburan dan keberhasilan hasil bumi adalah keyakinan yang tidak diperbolehkan dalam Islam. Selain itu, tradisi memasukan makanan, padi, singkong dan berbagai hasil bumi ke lubang yang telah disediakan sebelumnya oleh mereka dianggap sebagai wujud syukur ke bumi. Dalam perspektif Islam, hal demikian jelas bertentangan karena termasuk perbuatan mubazir (QS al Isra:27). Syukur dalam Islam dilakukan dengan tiga hal. Pertama, lisan seperti membaca hamdalah. Kedua, hati yakni menyadari bahwa apa yang dianugrahkan adalah pemberiah Allah SWT dan menerima yang yang telah ditetapkannya. Ketiga, dengan menggunakan apa yang dimilikinya sesuai cara dan tuntunan Islam.

\section{Daftar Pustaka}

Ahmad, As Sayyid al Hasyimi. tt. Mukhtar al Hadits. Indonesia: Putra Semarang.

Al 'Ajili al Syafii, Sulaiman bin Umar. tt. Tafsir al Futuhat al Ilahiyah, Jilid 2.

Al Jazairi, Abu Bakar Jabir. 1995. Minhaj al Muslim. Beirut: Dar al Fikr.

Al Muhilli, Jalaluddin Muhammad bin Ahmad dan as Suyuthi Jalaluddin Abdurrahman bin Abi Bakar. tt. Tafsir Jalalain. Beirut: Dar al Fikr.

Al Qasimi, Al Marhum As Syeikh Muhammad Jamaludin. tt. Mauidhah al Mu'miniin min Ihya 'Ulumuddin. Indonesia: Dar al-Ihya.

Al Samarqondi, As Syeikh Nasr bin Muhammad bin Ibrahim. tt. Tanbih al Ghafiliin. Indonesia: Dar al Ihya.

Al Utsaimin, As Syeikh Muhammad bin Shaleh. 2006. Syarah Riyadus Shalihin. Beirut-Libanon: Dar Ibnul Ashashah.

Ashari, Imam. 2001. Upacara Sedekah Bumi di Kabumen [Skripsi]. Yogyakarta: Jurusan Sejarah dan kebudayaan Islam IAIN Sunan Kalijaga.

Badrika, I Wayan. 2006. Sejarah Untuk SMA Kelas XI. Jakarta: Erlangga.

Bara Wati, Herliya. Pengaruh dan Nilai-Nilai Pendidikan Upacara Sedekah Bumi Terhadap Masyarakat. Jurnal Program Studi Pendidikan Bahasa dan Sastra Jawa UMP. Vol.2 No. 42013.

Moleong, Lexy. 2006. Metode Penelitian Kualitatif. Bandung: Rosdakarya.

el Harakah Vol.15 No.1 Tahun 2013 